\title{
Exu salva? Um percurso reflexivo nas encruzilhadas do imaginário
}

\author{
Jorge Gomes Junior ${ }^{1}$
}

Resumo: A partir de um curioso painel, dada a improbabilidade de se encontrar apontamentos de natureza semelhante àquela que exaltava a imagem de Exu, esse ensaio pretende refletir sobre a enigmática figura deste que é o mais intrigante dos orixás. Pensaremos o mistério que envolve esta força e refletiremos a relação de Exu com os pressupostos depreciadores que sustentam a discriminação, que serve de engrenagem para a intolerância religiosa. Bom ou ruim? Deus ou demônio? Afinal de contas quem é Exu? Não pretendemos aqui esgotar as reflexões sobre ele, mas desvinculados das teias do preconceito pensar esse sujeito, o entendimento sobre ele a partir de noções africanas, retomadas na diáspora, e as diferentes construções coloniais que o fizeram subjugado a um olhar pejorativo que se tornou senso comum.

Palavras-chave: Exu, Cultura afrobrasileira; Colonização; Intolerância religiosa

Resumen: A partir de un panel curioso, dada la escasa probabilidad de encontrar la naturaleza de notas similares a la que exaltó a la imagen de Eshu, este ensayo tiene como objetivo reflexionar sobre la enigmática figura de este que es el más intrigante de los orishas. Vamos a pensar en el misterio que rodea a esta fuerza y refletir la relación de Eshu con las presuposiciones de discriminación que sirve de engranaje a la intolerancia religiosa subyacentes . Bueno o malo ? Dios o el diablo ? Después de todo, que es Eshu ? No es nuestra intención aquí agotar la reflexión sobre él, pero desconectados de las redes de prejuícios pensar en este tema , la comprensión del mismo desde las percepciónes de África, que volveron a hacerse en la diáspora , y las diferentes construcciónes coloniales que le hizo subyugada a una mirada despectiva que se convirtió en el sentido común.

Palabras clave : Eshu , la cultura afro-brasileña ; la colonización ; la intolerancia religiosa

\footnotetext{
${ }^{1}$ Mestre em Relações Étnico-raciais (CEFET-RJ). Doutorando em Estudos de Literatura (UFF).
} 


\section{Introdução}

"Esù ó ó ni yágo loa/ Mo fori balé oo. Exu, abreme os caminhos/ Eu me prosto em reverência" Cantiga ioruba para Exu

Transitando pelos diversos itinerários da cidade do Rio de Janeiro é possível que se observe em alguns muros, bases de viadutos, entre outros lugares de intensa circulação de pessoas, como por exemplo a Avenida Brasil, via de grande porte que possibilita o acesso entre o centro da cidade e diversas áreas do subúrbio carioca e baixada fluminense, e também na Zona Portuária do município, pichações que insistentemente fazem referências pejorativas a figura de Exu.

As citadas inscrições que fazem alusão ao polêmico orixá dos cultos iorubas, que adaptados à realidade brasileira deram origem ao Candomblé, referem-se a essa divindade de maneira ampla, considerando inclusive as transmutações que ele sofreu ao longo da história, ao deixar de ser apenas parte do sagrado africano, que então se fez afrobrasileiro, passando a compor também o imaginário de outras tradições como a Umbanda.

Exu, Pombagira, Tranca Rua, todas essas nomenclaturas que no senso comum, em decorrência do olhar colonial perpetuado, apontam para ícones que são tratados como reflexos do próprio demônio, são citados em diferentes lugares da cidade, sempre formando um sistema de oposição ao salvador, na perspectiva cristã, a partir de citações que afirmam que somente Jesus expulsa essas figuras. Com grafia de estilo semelhante, outras pichações afirmam: Só Jesus salva.

Em setembro de 2012, no III Congresso Pensando Áfricas e suas Diásporas, promovido pela Universidade Federal de Ouro Preto, me deparei no ambiente 
acadêmico com um enorme painel que enaltecia a figura de Exu à medida que afirmava: Exú Salva. A surpresa do encontro promoveu uma série de reflexões a respeito da profundidade daquela afirmativa que, de certo, surgia como resposta a tantas investidas, naturalmente admitidas como verdade, que conferem ao orixá Exu um olhar negativo e até depreciador, caracterizando-o com a roupagem da figura mais desprezível para a lógica cristã: o diabo.

Da origem aos nossos dias: o olhar colonial e a desconstrução da figura de Exu

A colonização traz como pressuposto a arte da dominação para o crescimento, sem o reconhecimento de limites ou escrúpulos para o desenvolvimento dessa tarefa. Nesse processo, tudo que está ao alcance do olhar do dominador e pode ser convertido pelo mesmo em moeda, terá esse destino. Considerando o processo de colonização no continente africano e também no Brasil, podemos dizer que transformados em peças, negros escravizados, "Aprisionados no calabouço das aparências, passaram a pertencer a outros, que se puseram hostilmente a seu cargo, deixando assim de ter nome ou língua própria” (MBEMBE,2014, p.12), com a pretensão de esvaziar de identidade esses corpos, transformados em objetos, para que assim fossem mercadoria de fácil adaptação.

Com as mais variadas artimanhas para a opressão e, posterior ou simultânea imposição de seus valores, nos parece que a arma de efeito mais duradouro utilizada pelo processo colonial foi o forjar dos imaginários. É sabido que a dominação vai além de uma intervenção com armas ou caráter bélico. A criação de um imaginário reducionista foi capaz de convencer a muitos que a África e suas civilizações não têm uma história que anteceda a chegada do colonizador. A colonização se pautou no apagamento dos rastros. O colonizador se empenhou no silenciamento dos valores e culturas negro-africanas, não logrando êxito absoluto, mas deixando reticências que em seus desdobramentos geram, ainda hoje, profundos danos à sociedade. 
Houve, para que se cumprissem os planos do colono, a necessidade do intento de apagar a sapiciência e cultura do colonizado, a fim de recriá-las de acordo com suas necessidades, no intuito de estabelecer um processo de adestramento.

À medida que oferece ao seu campo de visão o caráter inaugural de todas as coisas, e como parte da camada que se veste de superioridade, o dominador pretendeu assassinar a alteridade de seus escravizados. Fazendo tábula rasa de toda e qualquer vivência anterior a sua chegada, cria uma história e estabelece julgamentos que dialogam com seus conhecimentos, considerados a verdade, à medida que ocorre também, como afirma Walter Mignolo (2003), uma colonização epistemológica norteada pelo etnocentrismo e eurocentrismo.

$\mathrm{Na}$ esteira desse processo, como parte da cultura do escravizado, o culto aos orixás é visto de maneira distorcida e arbitrariamente condenado. A religiosidade, a incorporação das raízes dos antepassados foram meios para que os corpos em vias de "esvaziamento", de alguma forma, se refizessem e automaticamente formassem frente ao ideal altericída do colono. A partir da resistência com sua fé, o princípio da desarticulação dos escravizados engendrada, por exemplo, por intermédio da congregação entre línguas diferentes, além da interação entre etnias por vezes rivais, sucumbiu. Resistindo a toda sorte de contratempos, a religiosidade africana se reconstrói no Brasil, retomando valores da terra ancestral e pagando o preço por subverter a ordem colonial de extinção dessa cultura.

Desde o primeiro encontro com o olhar dominante, o que se deu com os jesuítas, a divindade vinculada a liberdade, a sexualiadade, a libertinagem foi interpretada como a besta, figura que lhes é apresentada nesse embate inicial, haja vista que a mesma não compõe o universo religioso negro-africano. Exú é: 
[...] astucioso, grosseiro, vaidoso, indecente, a tal ponto que os primeiros missionários, assustados com essas características, comparam-no ao diabo, dele fazendo símbolo de tudo o que é maldade, perversidade, abjeção, ódio, em oposição à bondade, à pureza, à elevação e ao amor de Deus. (Verger, 2009 , p.136)

Narrando a introdução de Exu no mundo, o antropólogo Pierre Verger afirma que: "Como orixá, diz-se que ele veio ao mundo com um porrete, chamado ogò, que teria a propriedade de transportá-lo, em algumas horas, a centenas de quilômetros e de atrair, por um poder magnético, objetos situados a distâncias igualmente grandes." (VERGER,2009,p.136). Esse porrete, considerado um ícone de Exu também contribui para que mesmo antes da travessia pelo Atlântico Exu fosse mal visto.

Entre os fon do ex-Daomé, Èsù Légbára tem o nome de Légba. Ele é representado por um montículo de terra em forma de homem acocorado, ornado com um falo de tamanho respeitável. Esse detalhe deu motivo a observações escandalizadas, ou divertidas, de numerosos viajantes antigos e fizeram-no passar, erradamente, pelo deus da fornicação. Esse falo ereto nada mais é do que a afirmação de seu caráter truculento, atrevido, sem-vergonha e de seu desejo de chocar o decoro. (Verger, 2009, p. 138)

A incapacidade de ler os símbolos oferece a Exu o caráter de pervertido, o que atrelado às demais leituras já citadas, foi suficiente para determinar que ele, assim como a religiosidade que o tinha como participante fundamental, "canal de comunicação que interpreta a vontade dos deuses e que leva a eles os desejos humanos." (MARTINS, 1997, p. 26) fossem esconjurados. 


\section{De assombração a assombrado}

Pensando a fantasmagoria, no livro Fantasmas e Fantasias Imperiais no Imaginário Português (2003), Roberto Vecchi pensará no capítulo Das relíquias às ruínas. Fantasmas imperiais nas criptas literárias da Guerra Colonial, a figura do Fantasma e irá considerar que seriam eles silenciados da história que retornam para dizer, afirmar ou reafirmar o que não conseguiram ou não lhes foi possível dizer. Seriam então os fantasmas, para além do entendimento do espectro, retornados do silêncio com intuito de provocar o pensamento. Compreendemos que a estética imperial tende a totalização do outro, o que consiste na redução do mesmo a sua compreensão, a partir de seus pressupostos. "[O] pensamento europeu sempre teve tendência para abordar a identidade não em termos de pertença mútua (co-pertença) a um mesmo mundo, mas (...) no seu próprio espelho" (MBEMBE,2014,p.10). Dessa forma, a interpretação do mundo e tudo que existe nele, partindo de um remetente europeu, se fez em um processo de reflexo da autocontemplação.

Nessa linhagem se estabelece a dicotomia entre Nós e Eles, oferecendo a ambos, nesse sentido, o caráter de pronomes discriminatórios. A partir dessa dicotomia se fomentará o culto a diferença como algo determinante para atrair ou repelir, sendo o diferente sempre desabonado. No pensamento colonial e colonizado esse mecanismo propõe segregações e de alguma maneira, estabelece o par antagônico civilização/barbárie, estando a primeira no poderio do colono, enquanto a segunda seria a arte do colonizado, que encontrará na dominação um processo civilizador.

Na suposta investida civilizatória e reducionista, o colonizador reduz Exu e as culturas religiosas africanas ao status do primitivo e os associa ao que lhe parece mais apropriado. Esse julgamento faz de Exu um fantasma negro-africano, sendo nesse sentido um espectro, como a tradição cultural não africana nos 
entregou, com seus traços peculiares a corporificação ou visão imaterial do traspassado (fantôme). Um espírito perturbador, que poderia assombrar, de alguma forma, o espaço de circulação ou atuação da religiosidade negra. Nessa perspectiva, seria Exu uma assombração.

Sob a roupagem fantasmagórica, seria ele um fantasma que é, talvez, desejado pela habilidade que lhe é atribuída e repugnado por ser humano demais para ser divino. E essa dualidade de concepções parte, mais uma vez, de uma imagem idealizada do divino, resquícios de percepções de outra tradição religiosa, que não o define, não o conhece e por isso não pode ser padrão para conceituá-lo. Exu é divino em sua totalidade e humano em cada parte de si. E essa construção só parece contraditória se partimos da premissa de um divino que não cabe na humanidade. Todavia, Exu, muitas vezes o instaurador da desordem, se faz assim um provocador, que nos obriga a perceber a sacralidade a partir de outro prisma.

Exú revela-se, talvez, dessa maneira o mais humano dos orixás, nem completamente mau, nem completamente bom. Ele tem as qualidades dos seus defeitos, pois é dinâmico e jovial, constituindo-se, assim, um Orixá protetor (Verger, 2009, p. 136).

Sendo assim, compreendemos que seja ele um ser assombrado. O que nos parece realmente um fantasma é o imaginário forjado pela colonização que atribui a ele um lugar ínfimo que se faz verdade para tantas mentes colonizadas. O fantasma, nesse sentido, é compreendido como um rastro, calcado no passado, reticente no presente e criador no futuro, que mantem o que não ficou resolvido. A colonização é um fantasma que assola a figura de Exu e das religiões de matrizes africanas. Essa sobrevivente do passado não foi execrada. Temos corpos livres, mas ainda sofremos com mentes colonizadas. 
Como produto desse fantasma, temos a intolerância religiosa. Supostamente em nome de Deus, todos os ensinamentos desse mesmo Deus são simultaneamente negados, a barbárie se faz motor e o desrespeito, as agressões fazem sombra aos movimentos não cristãos, em especial aos cultos de matrizes africanas, que são vistos pelos intolerantes como um culto do inimigo de Deus. Esse movimento de retorno ao passado que têm argumentos tão legítimos quanto os da inquisição, ou seja, é injustificável, vem se mostrando recorrente entre ortodoxos e muitas vezes se maquia de uma naturalidade, encoberta erroneamente pelo discurso da liberdade de expressão, que não certifica o desrespeito.

Agredir em nome da fé é um retrocesso. O enfrentamento por parte das religiões afrodescententes, tem como lema o combate à intolerância religiosa, entretanto é preciso considerar que, partindo do entendimento etimológico do vocábulo tolerância, que traz uma noção de superioridade de algo ou alguém que suportará uma coexistência, o que se busca não é tolerância, mas respeito. Mesmo em desacordo com a terminologia adotada pelo movimento, consideramos louvável e legítimo o seu exercício.

É preciso identificar os fantasmas que habitam em nós e nos outros e considerar também que existem fantasmas híbridos. Os olhares se entrecruzaram e o fantasma criado pelos outros pode fazer morada também em nossos pensamentos. Estes são fantasmas de nós, terceira pessoa do plural e substantivo. É preciso desatar esse nó que a colonização deu e exumar esse fantasma, para que se acertem as contas com o passado, se crie um novo presente e se possa sonhar, sem ser utópico, com um futuro com mais equidade. Para exumar os fantasmas coloniais, que em diálogo com Mignolo (2003) podemos chamar de colonialidades modernas, que de alguma maneira seriam essas heranças ou resquícios coloniais que vivem em nós, exige alta dose de consciência histórica.

\section{Mas afinal de contas, quem é Exu?}


Por mais que lutemos contra a afirmação desses estereótipos que, equivocadamente, são utilizados para fundamentar o preconceito no que tange às religiões afrobrasileiras, resta saber se é do interesse de Exu que esse ethos seja desarticulado. Ele é irônico, provocador, gosta de gerar desconfortos quando destratado ou esquecido.

Segundo Pierre Verger "Exu é o guardião dos templos, das casas, das cidades e das pessoas. É também ele que serve de intermediário entre os homens e os deuses. Por essa razão é que nada se faz sem ele e sem que oferendas lhe sejam feitas" (VERGER, 2009, p.136).

Provocados pelo teor ideológico das opostas inscrições sobre Exu em âmbitos públicos de diferentes localidades do país, apoiados por toda essa reflexão que nos parece deixar objetivamente posto que o problema com a figura de Exu, para além de diferentes concepções de sagrado é uma herança colonial e perpetuá-la é alimentar a colonialidade dentro de nós, fortalecendo a perversidade colonial de reduzir a um modelo etnocêntrico e eurocentrado toda e qualquer coisa, afirmamos em concordância com o painel mineiro que Exu Salva.

Pensando as encruzilhadas de Exu podemos considerar que:

a encruzilhada é um princípio de construção retórica e metafísica (...) utilizado como operador conceitual, oferece-nos a possibilidade de interpretação do trânsito sistêmico e epistêmico que emergem dos processos inter e transculturais, nos quais se confrontam e dialogam, nem sempre amistosamente, registros, concepções e sistemas simbólicos diferenciados e diversos.(Martins,1997, p.28) 
Compreendendo a encruzilhada como um entrelugar, entendemos que a ela está reservada, também, a capacidade de gerar diversos signos e sentidos. Exu se faz o intermediário de todo processo de criação e interpretação do conhecimento e como energia vinculada à encruzilhada transita entre os diversos signos e sentidos.

Como precursor da comunicação, da compreensão linguística, por meio de sua provocante imagem e diferentes percepções a respeito de seu caráter, Exu nos faz pensar e nesse exercício nos salva da ignorância, nos instiga a olhar a sacralidade por outra ótica e nos evidencia a fluidez dos limites do divino, tendo no evento cultural a dinâmica dessa fluidez.

Inspirado por Exu e tentando defini-lo, podemos dizer:

Laroiê

Ele canta, ele dança, ele da gargalhada

Brinca na rua, gira na encruzilhada

Não dispensa oti² ${ }^{2}$ seu Axé cheira a dendê

Confunde, derruba, responde, levanta e lhe diz: Kiloxê3?

Mata um pássaro hoje com a pedra que atirou ontem.

Pode parecer menino, mas tem força de grande homem.

Homem da comunicação, da interação, que pode fazer união, Mas também gosta de confusão.

Ele conhece todo mundo. É amigo de muita gente.

Gosta de ser reconhecido, lembrado, homenageado

E com isso fica contente.

Não é de meias palavras. É de impulsionar os discursos.

O amigo não é o diabo, mas brinca com todo mundo.

É arteiro, curioso, feiticeiro, e quando é preciso sabe ser ardiloso.

\footnotetext{
${ }^{2}$ Do ioruba: Cachaça

3 Do ioruba: Vulgarmente: o que é? ou Quem é você?
} 
É homem com tudo lhe permite a humanidade

E mesmo assim não perde a divindade.

Princípio do movimento, da ação e da magia

Sabe de todas as histórias do mundo

Conhece a dor, mas gosta mesmo é de alegria

Não se importa com o que dele dizem e sempre tem muito a dizer

Sua verdade nem sempre agrada aquele que ouve

Mas é verdade, pode crer!

Acredite também que ele não é o diabo

O amigo é homem valente, pode até ser indecente

De certo não é bobo, não tem vocação para otário

$E$ às vezes, por que não?

É sim mercenário

Mas é assim porque conhece a ingratidão

Sabe como é volúvel essa gente,

Mesmo que nem todos sejam assim não

Prefere garantir o seu quinhão

Que ficar a ver navios depois de se desdobrar

Fazer ou desfazer aquela confusão, trazer solução

E ouvir o hipócrita dizer que não queria isso não

Não se esqueça...

Exu conhece o seu coração.

\section{Referências}

MARTINS, Leda Maria. Afrografias da memória: O Reinado do Rosário no Jatobá. São Paulo: Perspectiva; Belo Horizonte: Mazza Edições, 1997.

MBEMBE, Achille. Crítica da razão negra. Tradução: Marta Lança. Editora Antígona. 2014.

MIGNOLO, Walter. Histórias locais/projetos globais: colonialidade, saberes subalternos e pensamento liminar. Belo Horizonte: Editora UFMG, 2003. 
SANTOS, Juana Elbein. Os nagô e a morte - Pàde, Àsese e o Culto Egun na Bahia. Salvador: Editora Vozes, 2008.

VECHI, Roberto. Das relíquias às ruínas. Fantasmas imperiais nas criptas literárias da Guerra Colonial. in Margarida Calafate Ribeiro-Ana Paula Ferreira (orgs.), Fantasmas e Fantasias Imperiais no Imaginário Português Contemporâneo, Porto, Campo das Letras, 2003, pp.187-202

VERGER, Pierre. Orixás - Deuses Iorubás na África e no Novo Mundo. Salvador: Corrupio. 2009. 